\title{
FABRIG AND ORIGIN OF LATERAL MORAINES, BETHARTOLI GLACIER, GARHWAL HIMALAYA, INDIA
}

\author{
By Gerald D. Osborn
}

(Department of Geology, University of Calgary, Calgary, Alberta $\mathrm{T}_{2} \mathrm{~N}_{\text {r N}}$, Canada)

\begin{abstract}
Unusually strong till fabrics in lateral moraines of Bethartoli Glacier provide information on the genesis and growth of the moraines. On the west side of the valley, down-stream of the present glacier snout, several lateral moraine crests are juxtaposed. Because the crests generally become higher towards the valley axis, they must represent re-advances of the glacier rather than recessional stages. On the east side of the valley only a single lateral ridge is found; presumably the ridge is composed of debris from several glacial advances. On the eroded proximal flank of this ridge a strong fabric is visible; the plane defined by $a$ - and $b$-axes of stones is parallel to the distal flank of the moraine ridge, indicating that the moraine grew mainly by accretion of debris on to its distal flank. On the eroded proximal flank of the innermost west-side ridge the equivalent fabric is weaker, suggesting that distal flank accretion was less significant and proximal flank accretion more significant than on the east side.
\end{abstract}

RÉsumÉ. Origine et constitution des moraines latérales du Bethartoli Glacier, Garhwal Himalaya, Inde. Une texture inhabituellement forte de l'argile à blocaux dans les moraines latérales du Bethartoli Glacier donne des renseignements sur la génèse et la croissance des moraines. Sur le côté Ouest de la vallée, à l'aval de la langue actuelle, plusieurs cordons de moraines latérales sont juxtaposés. Comme ces cordons deviennent en général plus haut quand on va vers l'axe de la vallée, ils doivent représenter de nouvelles avancées du glacier plutôt que des stades de recul. Sur le flanc Est de la vallée, on n'a trouvé qu'une seule ride morainique; probablement cette ride est composée d'apports venant de plusieurs avancées glaciaires. Sur le flanc érodé le plus proche de cette moraine on peut voir une organisation très nette de la texture; le plan défini par les axes $a$ et $b$ des blocs est parallèle au flanc le plus éloigné de la moraine, ce qui indique que la moraine grossit surtout par accumulation de matériaux le long de son flanc le plus éloigné. Sur le flanc érodé le plus proche du cordon le plus interne sur la rive Ouest, l'organisation équivalente de la texture est moins évidente. On pense que l'accumulation sur le flanc le plus éloigné est moins nette et l'accumulation sur le flanc le plus rapproché plus abondante qu'en rive Est.

Zusammenfassung. Bau und Ursprung von Seitenmoränen am Bethartoli Glacier, Garhwal-Himalaya, Indien. Ungewöhnlich starke Schuttstrukturen in Seitenmoränen des Bethartoli Glacier liefern Informationen über die Entstehung und das Wachstum der Moränen. Auf der Westseite des Tales, unterhalb der heutigen Gletscherzunge, liegen einige Kämme von Seitenmoränen nebeneinander. Da die Kämme im allgemeinen gegen die Talachse hin höher werden, müssen sie eher Vorstössen des Gletschers zuzuordnen sein als Rückzugsstadien. Auf den Ostseite des Tales findet sich nur ein einziger seitlicher Moränenrücken; er ist vermutlich aus Schutt von mehreren Gletschervorstössen zusammengesetzt. An der erodierten Innenflanke dieses Rückens sind kräftige Strukturen zu erkennen; die durch die $a$ - und $b$-Achsen von Geröllen definierte Ebene ist parallel zur Aussenflanke des Moränenrückens, woraus folgt, dass die Moräne hauptsächlich durch Schuttzuwachs auf ihrer Aussenflanke zunahm. An der erodierten Innenflanke der innersten Moräne auf der Westseite ist die entsprechende Struktur schwächer; daraus lässt sich schliessen, dass der Zuwachs auf der Aussenflanke stärker, der auf der Innenflanke hingegen als auf der Ostseite war.

\section{INTRODUCTION}

Unusually strong till fabrics occur in lateral moraines associated with Bethartoli Glacier in the Garhwal Himalaya of India. The fabrics provide information on the nature of lateral moraine genesis, a subject about which very little is known.

Bethartoli Glacier is located in the so-called Nanda Devi Sanctuary, a rugged, relatively inaccessible drainage basin dominated by its namesake peak (Fig. r). The glacier and its immediate neighbour, Trisul Glacier, together cover a large part of a small valley called Trisul Nala. The lower part of Bethartoli Glacier, about which the moraines in question are located, is a small valley glacier which emanates from an ice cap straddling the flanks of Bethartoli Himal. The bedrock in the area consists of phyllites, schists, quartzites, and minor conglomerates of the late Precambrian Martoli Formation (Gansser, 1964). The foliated rock weathers into slabs of various sizes (both blades and disks in the Zingg classification) which make up the coarse fraction of the tills in the valley.

Glacial deposits in Trisul Nala were studied in conjunction with a climbing expedition to Devistan I, which overlooks Trisul Nala. 


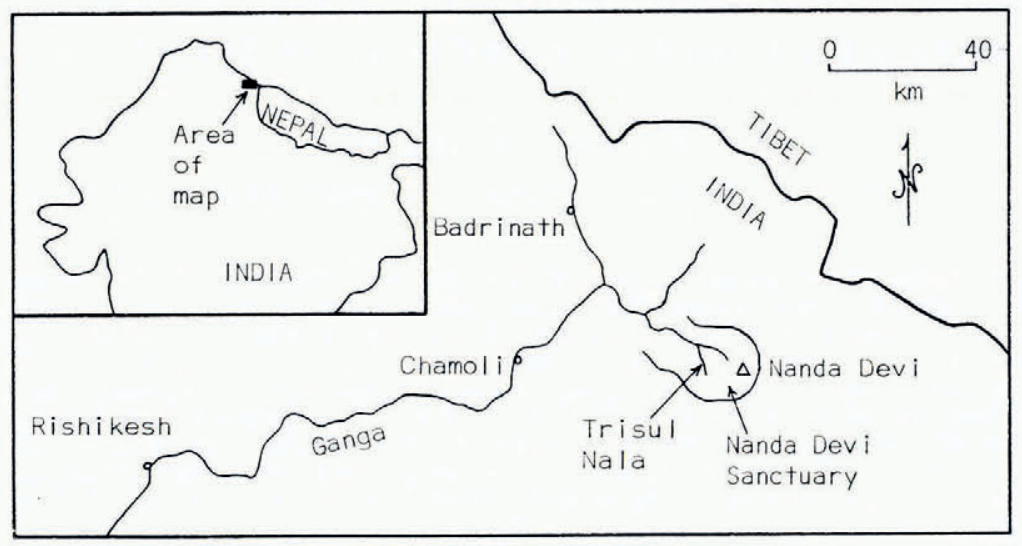

Fig. I. Index map.

\section{Previous WORK}

Lateral moraine tabric has been measured in various places by Galloway (1956), King (1969), and Mills (1977). Galloway, studying moraines in Lyngsdalen, Norway, found that long axes of stones are oriented transverse to the directions of lateral moraine crests. $\mathrm{He}$ assumed, probably erroneously, that such a fabric was produced by lodgement of stones under the influence of laterally spreading ice. The assumption was made in order to satisfy the general truism that "stones are generally transported by the ice in an attitude parallel to its direction of motion" (Galloway, 1956, p. 732).

King found that long axes of stones also are oriented transverse to a lateral moraine crest (Linnet Glacier, Baffin Island), on both the proximal and distal flanks of the moraine. Stones on the distal flank have a component of dip away from the glacier, which King thought was related to the slope of the moraine flank.

Mills, in a study of glacial deposits associated with Athabasca Glacier in Alberta, found a strong fabric mode on the distal flank of a lateral moraine, transverse to the moraine crest and dipping away from the glacier. On the proximal flank he found two weak modes transverse to the crest, and one weak mode parallel to the crest (i.e. in the direction of ice flow). He concluded that debris on the distal side of the moraine consists of once superglacial debris which slid laterally down the side of the glacier, building up a bank of material along the glacier margin. Although he did not state it explicitly, Mills implied that the distal fabric was produced as debris slid off the ice and on to the distal flank of the growing moraine. He presumed that material now on the proximal side was englacial debris which melted out beneath a debris cover.

\section{THE DEPOSITS}

The lower half of the valley-glacier part of Bethartoli Glacier emanates from a narrow bedrock valley and extends out on to a relatively wide flat-bottomed valley. Lateral moraines bounding this lower part of the glacier are free-standing ridges; that is, they are not plastered against bedrock valley walls. The glacier presently terminates just short of the main valley bottom of Trisul Nala, but well-preserved lateral moraines extend about $\mathrm{I} \mathrm{km}$ down the valley bottom (Fig. 2). On the east side of the valley bottom only a single moraine ridge stands, while on the west side several ridges are nested (Fig. 3). A total of ${ }_{1} 3$ west-side crests can be counted, each of which stands as high as or higher than its adjacent outer neighbour. Crests are spaced on the order of 8-10 $\mathrm{m}$ apart, and relief between crests and adjacent swales 
for the most part ranges between $\mathrm{I}$ and $4 \mathrm{~m}$. The proximal flanks of the single ridge on the east side and the innermost ridge on the west side are being actively eroded; till is exposed in bare fluted faces sloping at angles between $45^{\circ}$ and $55^{\circ}$. The till is moderately stony with boulders (up to about $2 \mathrm{~m}$ in $a$-axis length), cobbles, and pebbles set in a sandy clayey matrix. In a few places in the east-side exposure, small lenses of sorted fine-grained sediment can be seen.

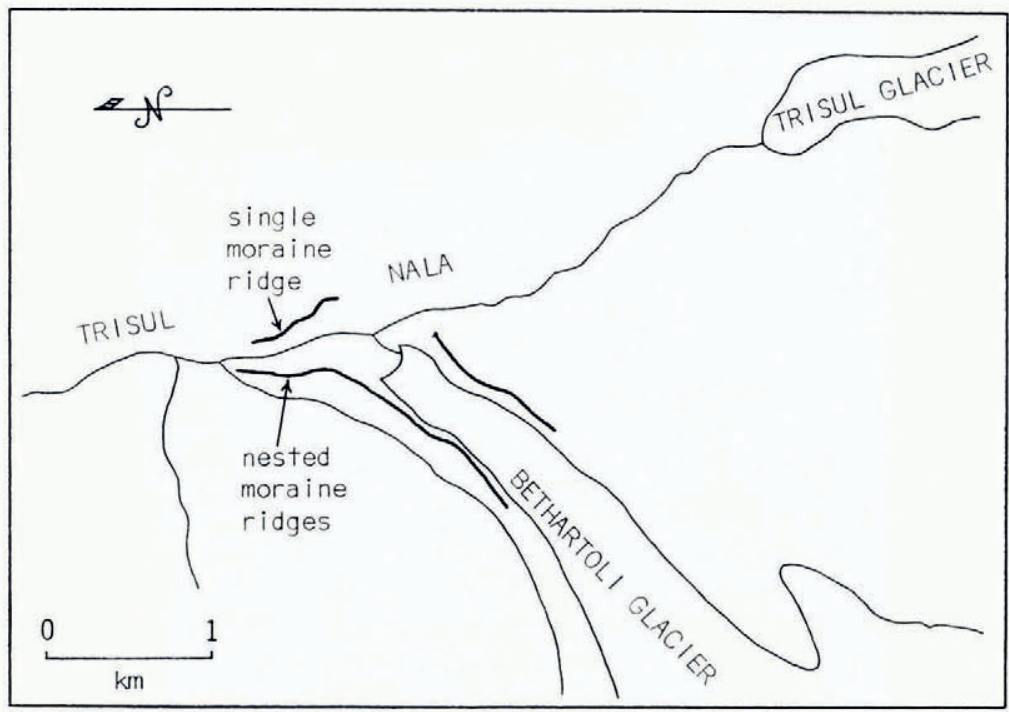

Fig. 2. Map of lower part of Trisul Nala. Bold lines represent lateral moraines.

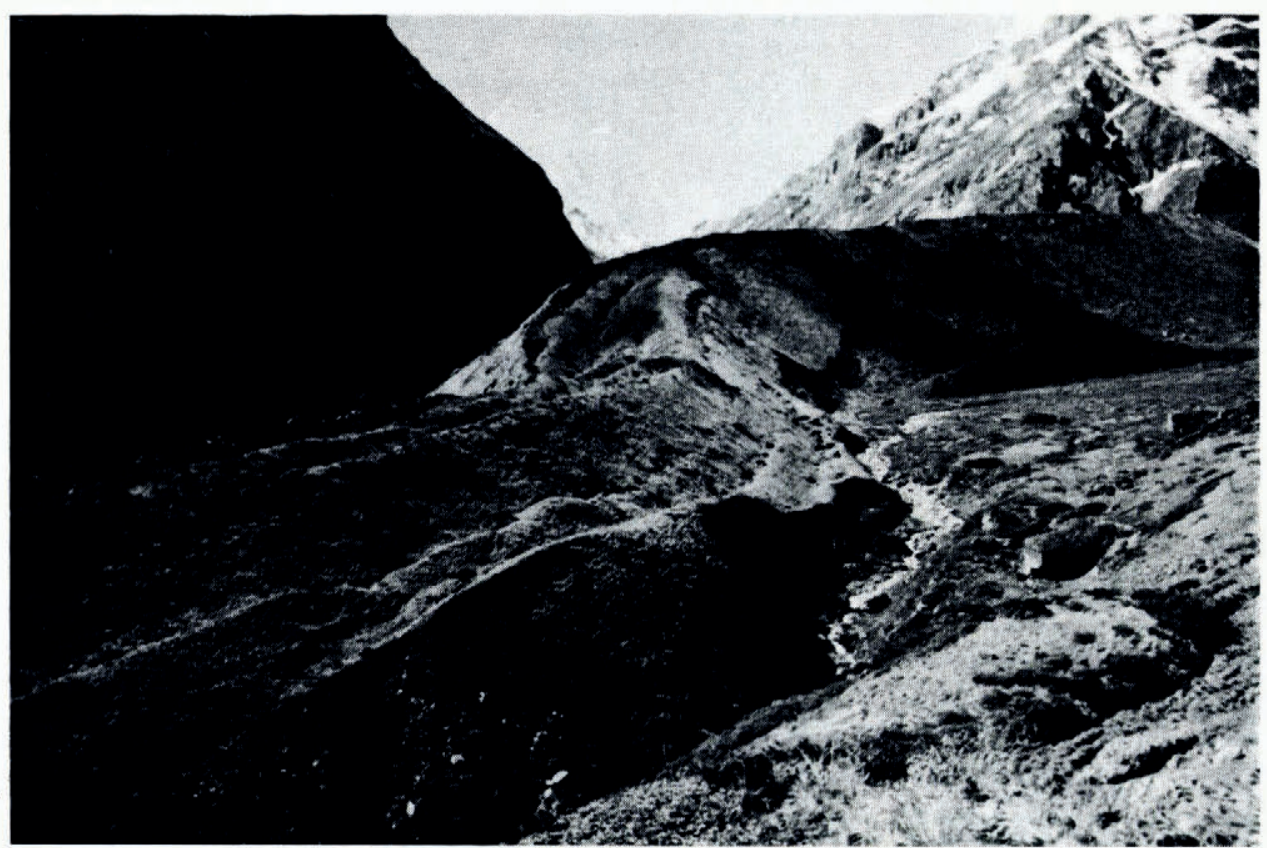

Fig. 3. Nested lateral moraines on the west side of Trisul Nala. Glacier was on left side of moraines and advanced several times from upper right to lower left of photograph. 
Near the present position of the glacier toe (Fig. 2), the several west-side crests merge into one another and only a single ridge exists on either side of the present lower end of the glacier.

In the eroded moraine faces a definite alignment of non-equidimensional stones is apparent. Fabric could not be measured quantitatively, because travel over the loose eroded faces was physically impossible and climbing equipment, in use elsewhere, was not available.

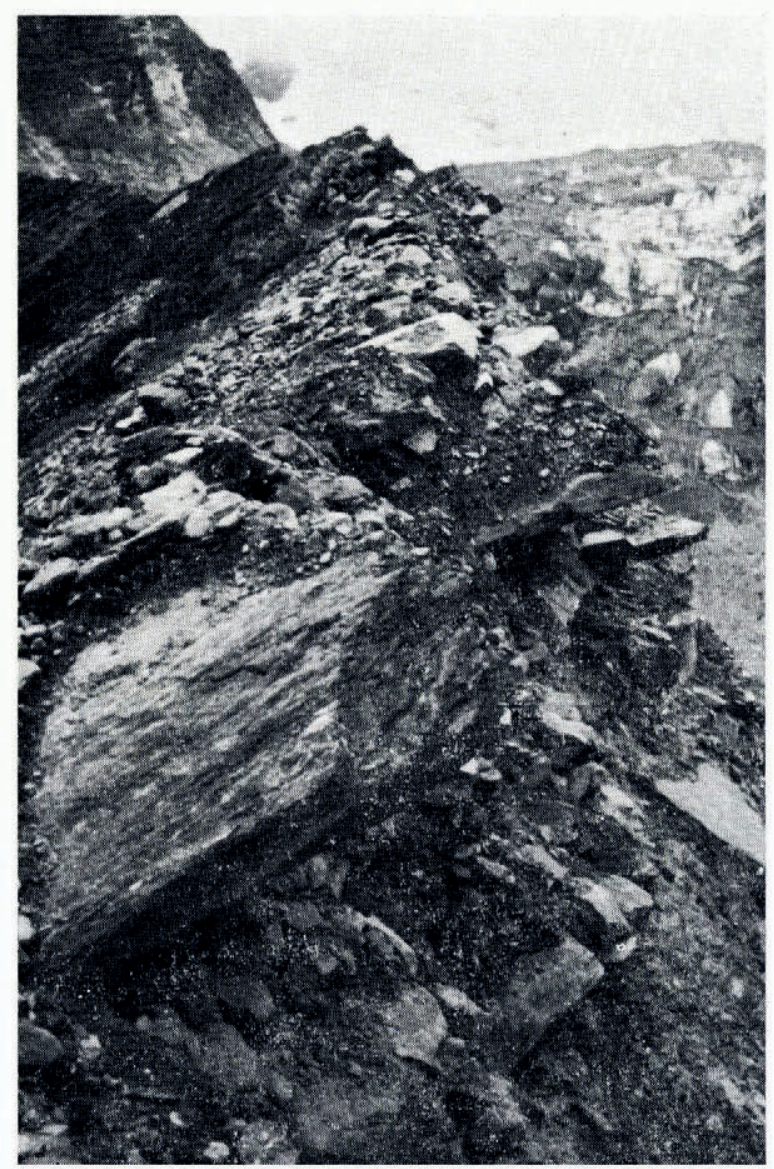

Fig. 4. Oriented clasts of metamorphic rock in eroded proximal flank of lateral moraine, south-east of present snout of glacier.

However, the qualitative descriptions recorded here can be verified at least in part by reference to Figures 4 and 5. Disk- and blade-shaped stones, which make up the majority of the pebbles-and-coarser fraction, tend to be aligned parallel to each other. The plane defined by the $a$ - and $b$-axes of these stones dips away from the valley axis (formerly glacier axis) at an angle of roughly $30^{-}-35^{\circ}$ (Fig. 4); in addition, there is a slight component of dip in the downvalley (down-glacier) direction (Fig. 5). This $a / b$ fabric is relatively strong on the east-side ridge, relatively weak on the innermost west-side ridge and moderate on the single ridges that line the sides of the present glacier. In most places no definite alignment of $a$-axes was obvious qualitatively, although in the exposure shown in Figure 4 many stones have their $a$-axes oriented transverse to the moraine crest and dipping away from the valley axis. 


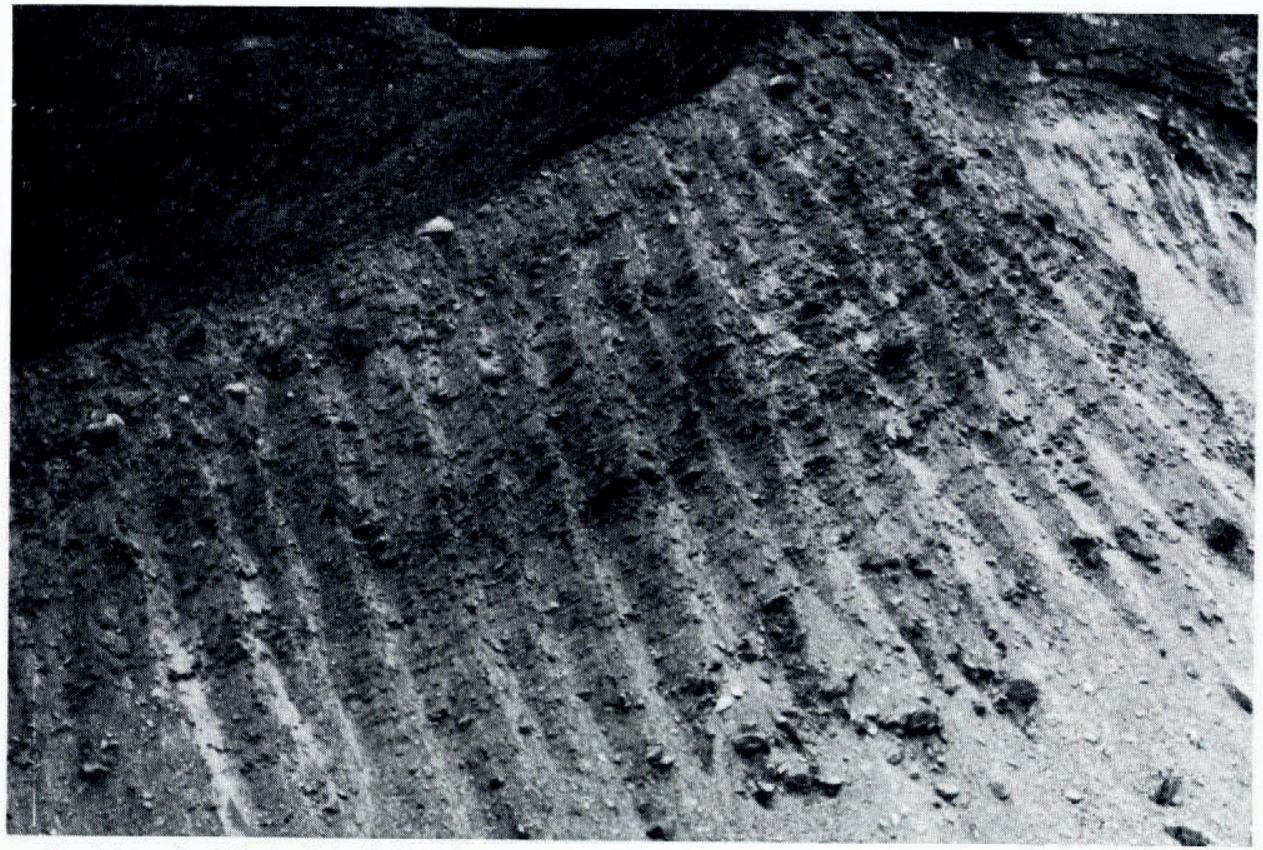

Fig. 5. Eroded proximal flank of single lateral moraine ridge on east side of Trisul Nala. alb planes defined by fat stones are parallel to the distal flank of the moraine.

\section{ORIGIN OF MORAINES AND MORAINE FABRIC}

The fact that the successive moraine ridges on the west side of the valley become higher towards the axis of the valley suggests that the ridges are not recessional moraines but rather were produced by successive re-advances of the glacier. Presumably, an equivalent east-side lateral moraine was built for every west-side lateral moraine; however, only one ridge stands on the east side. Consequently, debris must have been successively superimposed on the east side in such a manner that older moraine ridges were buried (Fig. 6). These differences in the way moraines were superimposed on one another probably accounts for the difference in fabric strength on the east and west sides. The east side will be considered first.

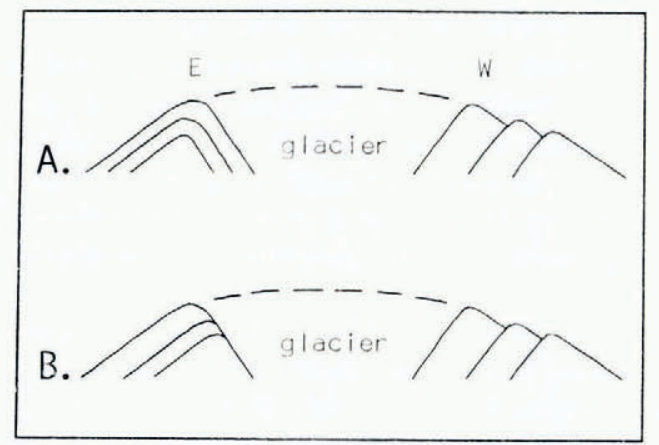

Fig. 6. Schematic transverse cross-sections showing possible arrangements of lateral moraine stacking (looking south down Trisul Nala). On the west side, moraines are nested against proximal flanks of older moraines.

A. On the east side, old moraines are buried by proximal and distal-flank accretion during successive advances.

B. On the east side, only distal-flank burial occurs; either non-deposition or erosion occurs on proximal flank. 
The plane defined by $a$ - and $b$-axes of stones parallels the distal flank of the single moraine ridge. The slight component of dip of the $a / b$ plane in the down-valley direction matches the down-valley elevation drop of the moraine crest. As the moraine ridge bends, the fabric defined by the $a / b$ plane bends with it (Fig. 5). These observations suggest an obvious genetic relationship: each of the oriented stones was accreted on to the distal flank of the moraine, or, in other words, the moraine grew mainly by accretion of debris on to the distal flank. The accreted material was probably mostly superglacial debris originally; the material may have slid down the sloping margin of the glacier and on to the moraine flank, as suggested by Mills (1977) in the case of Athabasca Glacier. Some of the material may have been subglacial debris, lodged between ice and already existing moraine at the extreme margin of the glacier, which, when exposed by ablation, slid down the distal flank.

No matter what the original disposition of the debris, the proposed mechanism requires that the slope angle of the distal flank $\left(30-35^{\circ}\right)$ be an angle of repose and that flat stones are able to move down the flank when the angle of repose is exceeded. This requirement may be more easily met if the surface of the moraine is wet, e.g. during spring snow-melt seasons; in such cases the fine-grained till matrix may provide some lubrication for sliding or creeping stones. It is also possible that stone creep is facilitated by slight heaving and subsiding of the moraine surface during freeze-thaw cycles.

The presence of some sorted fine sediments suggests that there occasionally were significant amounts of water somewhere near the ice-moraine interface. One possibility is that, during an advance, glacier ice bulges slightly above the moraine crest, in which case melt water may spill down the distal flank and accomplish some local sorting of sediments. During a retreat, if glacier ice is depressed slightly below the moraine crest, water may pond in the depression with resulting pond sedimentation.

A question arises as to the nature of deposition on the proximal flank of the moraine. One would expect coarse debris being sheared between ice and moraine to be oriented with $a / b$ planes parallel to the ice-moraine interface. Such a fabric (although quite a weak one) was found by Mills (1977) on the Athabasca Glacier moraine. However, no such fabric is evident in the exposed proximal face of the moraine in question. If till with that fabric ever existed, it has been eroded off. The amount of erosion that has taken place since ice retreat cannot be determined with any exactitude but it is estimated to be fairly minimal, because probable remnants of the moraine crest formed during the latest advance can be found. The conclusion is that the moraine, even before erosion, consisted almost entirely of distal-flank debris. Accretion on the proximal flank must have been minimal and successive burials of older moraines must have been accomplished as shown in Figure 6B. A corollary is that tills of several different ages may be present in the exposure shown in Figure 5 .

The situation is more complicated on the west side of the valley because successively younger moraines were plastered against older moraines, instead of overtopping them. The difference may be somehow related to the bend in the glacier as it reached the bottom of Trisul Nala and turned to the north (Fig. 2) but it is not clear why the glacier midline shifted slightly further east each time the glacier advanced. It may be that successive slight shifts of the glacier for some reason not related to the moraines caused the different styles of deposition on either side but it is also possible that the differing styles of deposition on either side caused the shifting of the glacier.

In any event, the weakness of the $a / b$ fabric in the till of the innermost ridge indicates that accretion of debris on the distal flank of the moraine was not as significant a process as on the east-side lateral moraine. Perhaps accretion of subglacial material on to the proximal flank of the moraine was equally important (although there is no apparent fabric parallel to the proximal flank). Nevertheless, some distal accretion did occur. A process such as illustrated in Figure 7 is envisioned. When the snout of the re-advancing glacier first arrives at a particular point, it is accompanied by subglacial debris which is being sheared between ice and the 


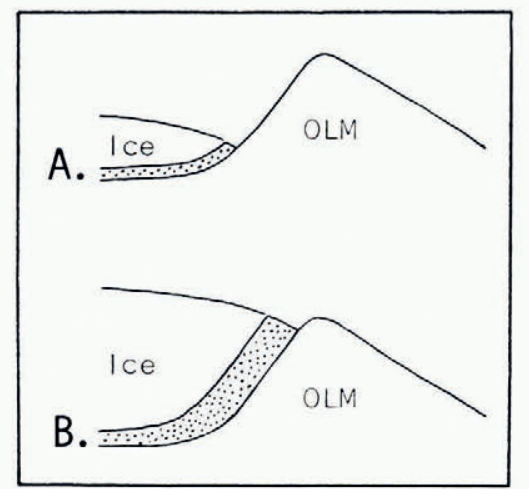

Fig. 7. Schematic transverse cross-section through glacier showing growth of new lateral moraine. Stipple indicates subglacial debris; OLM, older lateral moraine.

A. Snout of glacier has just advanced beyond section line.

B. Near time of maximum advance.

adjacent, older moraine flank. Thus from the outset there is a separation of ice from the older moraine and an opportunity for flat stones to be emplaced on the beginnings of a distal flank. As the glacier advances past that point and the ice becomes thicker, the moraine can grow both by sliding and rolling of stones on to the distal flank and by accretion beneath the margin of the ice. The result is a moraine which grows in thickness as well as height, and which will show a weak fabric parallel to the distal flank (hopefully, quantitative measurement would also demonstrate a weak fabric parallel to the proximal flank).

\section{ACKNowledgements}

I thank Ram Singh and the porters for letting me share their cave in Trisul Nala, and Cathy Langill and Angus Ferguson for a critical reading of the manuscript.

MS. received I6 November 1977

\section{REFERENCES}

Galloway, R. W. 1956. The structure of moraines in Lyngsdalen, north Norway. Fournal of Glaciology, Vol. 2, No. 20, p. $730-33$.

Gansser, A. I964. Geology of the Himalayas. London, Interscience Publishers.

King, C. A. M. 1969. Moraine types on Henry Kater Peninsula, east Baffin Island, N.W.T., Canada. Arctic and Alpine Research, Vol. I, No. 4, p. 289-94.

Mills, H. H. 1977. Differentiation of glacier environments by sediment characteristics: Athabasca Glacier, Alberta, Canada. Journal of Sedimentary Petrology, Vol. 47, No. 2, p. 728-37. 